\title{
Research on the Career Ability Demand and Training Mode of College Students Majored in Management
}

\author{
Qiu Dongfang \\ College of Economics and Management, \\ Nanjing University of Aeronautics and Astronautics, \\ Nanjing, Jiangsu, 211106, P. R. China \\ qdff99@163.com
}

\author{
Lu Chunyu \\ College of Economics and Management, \\ Nanjing University of Aeronautics and Astronautics, \\ Nanjing, Jiangsu, 211106, P. R. China \\ $1732969721 @ q q . c o m$
}

\begin{abstract}
Along with economic development, the demand on talents of management has expanded constantly in each field of the society, and the education and training of college students majored in management have become increasingly important. By analyzing the career ability demand of college students majored in management, this paper points out the basic ability, core ability and comprehensive ability to be owned by the college students majored in management, and brings forward related suggestions on training mode of college students majored in management, for example, we should make clear training objective, optimize the setting of training direction, strengthen teaching staff construction, and give full play to supervisors' instruction function, reform and innovate training method, attach importance to practice teaching, and establish interaction mechanism of college-enterprise, establish high-efficiency quality evaluation mechanism.
\end{abstract}

Keywords-college students majored in management; career ability demand; training mode; training objective

\section{INTRODUCTION}

At present, China enjoys fast economic and social development, and is in the critical period of economic structure adjustment and industrial transformation \& upgrading. Along with the subdivision of occupational division and the diversification of occupational types, each field of the society has had increasingly active demand on application-oriented talents majored in management. The occupation, complexity, and application of the college students majored in management have been gradually recognized by all fields, and enjoyed increasingly strengthened attraction. In this background, the scale enlargement of college students majored in management, on the one hand, is an interim policy to relieve employment pressure, and on the other hand, meets the active demand of the change of social and economic development method on various high-level application-oriented talents in China. Therefore, exploring the career ability demand and training mode of college students majored in management actively is a problem to be researched and solved urgently in present education of college students.

\section{CAREER ABILITY DEMAND OF COLLEGE}

\section{STUDENTS MAJORED IN MANAGEMENT}

In the era of knowledge economy, the integration of different disciplines and the development of each discipline in cross-range, depth and breadth have become increasingly obvious. The Outline of Planning for Medium- and Long-Term Education Reform and Development of China emphasizes that, we shall persist in attaching most importance to ability, optimize knowledge structure, enrich social practices, and strengthen ability training [1]. Therefore, college students majored in management must have corresponding abilities and qualifications; based on specialty learning, having related knowledge and theoretical background, they must have their own ability training strengthened, and thus become general talents meeting the requirements of the new era.

\section{A. Basic abilities}

\section{1) The ability to understand macroeconomic situation}

Macroeconomic policy indicates that the country or the government applies certain policy instruments consciously in a planned way to adjust and control the operation of macro-economy, in order to achieve certain policy objectives. Macroeconomic situation indicates the overall structure and operation status of national economy. The economic entities served by college students majored in management are a cell of national economy; the cell can only operate in the overall track of national economy, and carry out self-adjustment, perfecting and development constantly along with the adjustment of national macroeconomic policy and the change of macroeconomic situation. Therefore, college students majored in management shall have the ability to understand national macroeconomic policies and macroeconomic situations. Only in this way, could they, when participating in unit' $s$ economic management activities, make clear the situations, grasp the direction, help their unit to make the best of various beneficial conditions, avoid or correctly respond to negative conditions, and ensure the sustainable and healthy development of the unit' $s$ operation management activities [2](Zhao Yunjun, et al 2012) .

\section{2) The ability of knowledge skill}

College students majored in management belong to professional talents, and shall have the theoretical knowledge and research method. In terms of knowledge skill, students shall not only grasp solid fundamental theory and professional knowledge, but also have excellent application knowledge, broad humanistic and social knowledge. Meanwhile, they shall have certain in-depth knowledge, and understand the front-edge trend of economic management discipline and specialty deeply; based on grasping modern experiment methods and skills, occupational post practices and application ability, they shall grasp complete, systematic and scientific professional knowledge system by facing industries, and raised the depth of their cognition with the discipline's knowledge system.

\section{B. .Core abilities}

\section{1) Scientific research ability}

$\mathrm{Xu}$ Xiaolei think that with the development of China's economy and society and the further advancement of higher education reform, the current educational research work of our universities and the scientific research ability of our college students have made some progress. But due to subject to the traditional education system, mechanisms and other factors, 
there is still a big gap between the level of scientific research ability of our college students and the developed countries' college students in the west [3]. Raising management college students' scientific research is not only the motive power for discipline development, but also a necessary means for raising a country's soft strength. College students majored in management are an important integral part of Chinese scientific research team of economic management. Based on training objective, we should train college students majored in management actively on corresponding scientific research and innovation ability, make sure they do well in discovering problems from practical demand of economic and social development, abstracting and considering problems, and comprehensively applying theoretical knowledge, methods and techniques to solve problems.

\section{2) Practical ability}

The reason for China's postgraduates having difficulty in getting a job" rests with the separation of education from the market. President Yuan Shouqi of Jiangsu University has ever pointed out that, the appearance of difficulty in getting a job indicates that talent training at the layer of universities and colleges needs to be reformed, and the training shall not be divorced from reality, but shall strengthen students' practice ability. The education of college students majored in management is to train pragmatic talents, and such students' ability structure shall have somewhat difference from that of postgraduates. When emphasizing theoretical knowledge and research method, we shall attach importance to the training of practical ability and operating method, combine the two factors reasonably and effectively, in order to train compound talents. Establishing an evaluation system to evaluate the practical ability of college students majored in management and it may be done from two aspects, on the one hand, to examine the practice for college students to master degree, on the other hand, evaluation of university teachers' practical teaching ability is necessary.

\section{Comprehensive abilities}

\section{1) Learning ability section headings}

In the background of the times when the tide of knowledge economy sweeps across the globe and knowledge updating is constantly accelerated, knowledge-type talents usually play an increasingly obvious role in the proceeding of social advancement. College students majored in management need to keep learning after graduation and entering the society in order to meet the requirements of employers, and to be competent for the work posts constantly challenged by innovation, so their learning ability seems especially important. Along with the change of macroeconomic policies and economic situations, related rules and criteria have been constantly reformed. College students majored in management shall have the ability to keep learning and perfecting themselves, expertly grasp the latest changes of related criteria, in order to meet the demand of fast change and diversified development of the society, economy, technology and culture nowadays.

\section{2) Communication ability}

Modern education theory considers that, the training and education of communication ability could make a person have the ability to cognize himself, to understand and adjust others' sentiments, and to cooperate with others. College students majored in management in the new era shall have not only profound knowledge skills, excellent scientific research and practice ability, but also relatively strong communication ability, and this is also an important criterion for measuring whether a university could train talents useful to the society. Communication ability is especially important for college students majored in management, since they mainly deal with economic management work after graduation. Nowadays in the background of world economy integration, along with the mutual permeation of members of different cultures in organization, managers' communication ability has even become an important factor which affects the efficacy of management. Therefore, college students majored in management shall have good intercommunication ability to treat interest relationship in various aspects in economic management activities.

\section{TRAINING MODES OF COLLEGE STUDENTS MAJORED IN MANAGEMENT}

The education and training modes of college students majored in management shall meet social demand, and shall actively cultivate multi-layer, compound and innovative talents. The training mode shall be optimized based on the demand on the career ability on the college students majored in management, and in order to raise the quality of education.

\section{A. Making clear training objective, and optimizing the setting of training direction}

Set accurate training objective of college students majored in management accurately: Management professional covers broad fields, which have diversified demands; industrial development levels are different, the specifications for training of talents in different fields are different, and a same field has diversified talent demands. In the training of college students majored in management, we shall constantly strengthen the coordination with enterprises, correctly orient the training objectives of college students majored in management, and bring forward the abilities to be owned by the college students majored in management [4]( Dong Jian, Guo Ying,2013) .

The setting of training direction is a key section reflecting the school running characteristics, and also an important aspect embodying training unit's training quality, and it determines whether graduates' knowledge structure and ability structure meet the requirements on economic management talents at different posts. Therefore, training unit shall set up training direction according to future job posts. In this way, training unit could arrange and allocate education resources upon the demand of industrial posts, make teaching plan and training scheme pertinently, complete the education of knowledge and ability necessary for economic management talents of professional academic degree, make the talents trained be more suitable for post demands, and combine theory and practices more closely. After determination of training direction, the training unit shall determine oriented courses or course pool with distinctive characteristics. The courses in the course pool may be divided into required course and oriented optional course. The training unit shall truly train high-end talents of 
different orientations, in order to meet the demand of constant development of market economy and capital market still better.

\section{B. Strengthening teaching staff construction, and giving full play to supervisors ' instruction function}

On the one hand, powerful teaching staff provides reliable guarantee for training qualified college students majored in management. University teachers shall have high sense of responsibility, rigorous scholarship, strong innovation concept and lofty professional ethics. Aiming at the training objectives, university teachers shall have not only profound theoretical foundation and relatively strong scientific research ability, but also abundant practical experiences. On the other hand, we shall strengthen teachers' responsibility system, and straighten out the relationship between teachers and college students; strengthen teachers' awareness of responsibility, provide training and education for teachers, raise teachers' enthusiasm, and intensify supervisors' sense of responsibility for education and instruction; and thus promote teachers to pay attention to student education, instruct and encourage students to do exploration and innovation with utmost care, guide students to develop rigorous atmosphere of learning and research in virtue of their own knowledge, talent and ethics, and promote the enhancement of college students training level.

\section{Reforming and innovation training method}

In view of the requirements on the career ability of college students majored in management at present, universities and colleges shall carry out reform in the following several aspects:

- In terms of teaching method, case study may be adopted. The teaching process shall pay attention to the combination of theory and practice. The latest cases in capital market may be selected to strengthen the interest. In class, many methods like team learning, case study, field research, simulation training, group discussion, etc. may be adopted to encourage students to think actively and be brave in innovation, guide students to analyze and solve problems and compose analysis report, and thus raise their ability to analyze and solve problems.

- For courses of strong pragmatism, social elites and enterprises' senior executives, etc. who have solid theoretical foundation and are proficient in practice may be employed to act as lecturers of the courses, in order to strengthen students' interest in learning and their deep understanding on practices [5](Sun Jianhua,2013).

\section{Attaching importance to practice teaching, and establishing college-enterprise interaction mechanism}

College students majored in management mainly deal with economic management work after graduation, so they need to not only understand corresponding technical skills, but also have certain practical experiences. Constructing practice teaching base and strengthening the united training of schools and enterprises is not only to contact corresponding actual work unit, employ supervisors from there, and arrange some students to do practice there, but instead, as a systematic project for training college students majored in management, it shall attract much attention of both training unit and base, who shall carry out close cooperation and make considerate planning, make student learn corresponding technical and theoretical knowledge in schools, and then take exercise in enterprises. When selecting practice teaching base, we shall not only survey alternative enterprises' geographical location, business scale, management level and economic benefit, but also sufficiently their senior executives' theoretical foundation, scientific research potential, and the degree of passion for and attention paid to the construction of practice teaching base [6]( Zhang Shuwei, Niu Lirui., 2016). Only in this way, could we raise the quality of education on college students majored in management, and make them meet social demand and enjoy certain competitiveness after graduation.

\section{E. Establishing high-efficiency quality evaluation mechanism}

In terms of establishing quality evaluation mechanism, universities and colleges shall establish diversified quality evaluation standards based on the consideration from two aspects. The first is the evaluation of universities and colleges on students. The training objective is to make college students majored in management become special talents who have solid theoretical foundation and professional knowledge of economic management, as well as relatively strong ability to solve practical problems. Therefore, the schools shall perfect the assessment and evaluation mechanism from aspects of theoretical foundation and application, realize the evaluation on theoretical foundation through the assessment of course learning, and assess the degree of students' grasping of basic economic knowledge and front-edge theoretical knowledge about economic management; also, schools shall assess students' practical application ability mainly from the practice effect and graduation thesis design, and highlight the evaluation on the ability to solve practical problems [7](Ding Xiancun, Sun Yannan,2015). The second is the evaluation on universities and colleges' training quality. The evaluation system shall include the two levels, namely external evaluation and training unit's self-evaluation; and it shall include the sections like evaluation organ, evaluation object, evaluation index, evaluation procedure, evaluation method, etc. This evaluation system shall be used to constantly discover and solve problems, perfect universities and colleges' training models and training methods, and effectively realize students' training objectives.

\section{CONCLUSIONS}

In short, the education of college students majored in management is a new training model different from the college students of the science department, and it aims to train application-oriented talents with innovation ability, entrepreneurship ability and practice ability, and meet the demand of certain industry or occupation. Along with the development of economy, and the acceleration of economic structure adjustment and industrial transformation \& upgrading, the education of college students majored in management has become an inevitable trend for the education reform of management specialty, the education of college students majored in management should start with the training objective of college students majored in management, analyze the career ability demand of college students majored in management, actively explore and innovate talent training model, construct teaching plan, discuss practice teaching model, thus perfect the 
talent training and application system of college students majored in management, and provide services for training management talents demanded urgently by the society.

\section{ACKNOWLEDGEMENT}

The paper is supported by "the 13th Five-Year Plan for Undergraduate Course Construction of NUAA" and "the Fundamental Research Funds for the Central Universities" （NO.NR2016014）.

\section{REFERENCES}

[1] The State Council. National Medium and Long Term Education Reform and Development Plan(2010-2020 year)

[2] Zhao Yunjun, Liu Guangling. The training reform and exploration of economics \& orientation, law \& business characteristics, core capacity".
Journal of Xi'an University of Arts and Science (Social Sciences Edition), vol. 6, pp. 85-87, 2012.

[3] Xu Xiaolei. Obstacles to the cultivation of scientific research abilities of college students and the way to improve, Science and Technology of Chinese Universities, vol. 07, pp. 22-23, 2015.

[4] Dong Jian, Guo Ying. Promoting the reform of undergraduate training mode with innovative experiment of college students. Experimental Technology and Management, vol. 08, pp. 183-186, 2013.

[5] Sun Jianhua. Innovation of Model for Academic Degree Training of Accounting Masters-Based on the Orientation of Demand on High-End Accounting Talents. Finance and Accounting Monthly 16, pp. 122-124, 2013

[6] Zhang Shuwei, Niu Lirui. A Comparative Study on the Cultivation Model of Practical Ability between Chinese and Foreign College Students. Chinese adult education, 16, pp. 73-76, 2016.

[7] Ding Xiancun, Sun Yannan. An Analysis of the Elements of Constructing the Quality Evaluation Index System of College Students-Based on social adaptability in employment. Journal of Anhui Agricultural University, vol. 6, pp. 121-126, 2015. 